American Journal of Applied Sciences 6 (6): 1067-1069, 2009

ISSN 1546-9239

(C) 2009 Science Publications

\title{
Inhibitory Effect of Ginger Extract on Candida albicans
}

\author{
${ }^{1}$ Zahra Atai, ${ }^{2}$ Manijeh Atapour and ${ }^{3}$ Maryam Mohseni \\ ${ }^{1}$ Department of Oral Medicine, Faculty of Dentistry, \\ Kerman University of Medical Sciences, Kerman, Iran \\ ${ }^{2}$ Clinical Laboratory Doctor, Neuroscience Research Center, \\ Kerman University of Medical Sciences, Kerman, Iran \\ ${ }^{3}$ Dentist, Farhangian Dental Clinic, Khajoo Street, Kerman, Iran
}

\begin{abstract}
Problem statement:The fungal infections could be life-threatening in immunocompromised patients. Candida albicans is the most frequent fungi in the oral cavity. Approach: The first step for treatment could be done using topical antifungal agents. Nystatine is a choice for mentioned usage but there are some problems in its using including: unfavorite taste, frequency of usage, etc. Finding better replacements is the subject of many studies. Results: This study was carried out to find an alternative for Nystatine. The study was designed based on laboratory investigations to investigate the antifungal activity of zingiber offcinale (Ginger) on Candida albicans. Candida albicanse (PTCC 5027, ATCC10231) was obtained from Iranian microbial collection and was confirmed by Germ Tube formation test. Ethanolic ginger extract was prepared. The antifungal activity of the extract was determined using Agar dilution and disc diffusion techniques. Data were analyzed by ANOVA test. Conclusion/Recommendations:The results showed that the ethanolic extract was effective on Candida albicans $\left(2 \mathrm{mg} \mathrm{mL}^{-1}\right)$ at the concentration of 1:5. The study indicates that ginger extract might have promise in treatment of oral candidiasis.
\end{abstract}

Key words: Zingiber officinale, antifungal activity, Candida albicans

\section{INTRODUCTION}

The incidence of serious infections caused by yeast, particularly species of Candida, has increased dramatically during the past decade. Oral candidiasis, formerly dismissed as an simple infection occurring in denture wearers, is now one of the most common opportunistic infections in immunocompromised patients such those undergoing chemo therapy, HIVinfected persons and transplant recipients ${ }^{[1,2]}$.

There are topical and systemic antifungal agents that may be indicated to control oral candidiasis, but, the development of resistance is an emerging trend that may threaten their clinical effectiveness ${ }^{[1-4]}$. For millions of people that traditional medicine serves as the only opportunity for health care, plants are vital sources. Safety and lower side effects of many herbal extracts have also suggested them as sources of new pharmaceuticals ${ }^{[5-8]}$. History of ginger and its applications are well documented ${ }^{[9,10]}$. It has been in medical use since ancient times. Ginger is listed in modern pharmacopoeias and repertories and has a wide range of confirmed pharmacological properties ${ }^{[11-13]}$. More recently studies have shown the antifungal properties of ginger extract, Gingerol ${ }^{[13]}$.

In this study the antifungal activities of ethanolic extract of the rhizomes of "zingiber officinale" on Candida albicans was investigated.

\section{MATERIALS AND METHODS}

The fungi used in this study, Candida albicans (PTCC 5027 and ATCC 10231), was purchased from Iranian microbial collection (Tehran, Iran). Candida albicans was cultured and maintained on subouraud's dextrose agar medium at $30^{\circ} \mathrm{C}$. Inoculums of yeast like fungi were prepared for disc diffusion assays. Sterile $705 \mathrm{~mm}$ diameter paper discs (3M, USA) were impregnated with $2 \mathrm{mg}(10 \mu \mathrm{L})$ ethanolic plant extract, allowed to air dry and placed face down on the inoculated agar surface. Nystatin solution 100000U/CC used as positive control. Discs impregnated with $10 \mu \mathrm{L}$ of $1 \%$ normal saline and allowed to air dry served as negative control. Plates were then incubated at $30^{\circ} \mathrm{C}$ in dark for $48 \mathrm{~h}$, after which the diameter of the fungal

Corresponding Author: Zahra Atai, Department of Oral Medicine, Faculty of Dentistry,

Kerman University of Medical Sciences, Kerman, Iran

1067 
growth inhibition zone was measured. The well containing the highest dilution of ginger extract that still showed a zone of inhibition around it was considered to be $\mathrm{MIC}^{[14,15]}$.

Extracts was prepared by blending approximately $500 \mathrm{~g}$ of the preserved plant material in $99 \%$ ethanol (1:3 (W/V) ratio). The mixture was filtered and the filtrate was retained and the residue was again stored in fresh ethanol and processed as above. The filtrates were collected and the solvent was rotary evaporated at $45^{\circ} \mathrm{C}$ to near dryness, whereupon the extract was freeze-dried for $48 \mathrm{~h}$ to achieve complete dryness.

The process yielded approximately 35-45 $\mathrm{g}$ of dried extract. The dried extract $(200 \mathrm{mg})$ was reconstituted in $1 \mathrm{~mL}$ of $99 \%$ ethanol for a final concentration of $10 \mathrm{mg} \mathrm{mL}^{-1}$ for antifungal disk assays. Data were analyzed by ANOVA test.

\section{RESULTS}

The ginger extract was effective in inhibiting the growth of Candida albicanse. The positive control (Nystatin) produced significantly sized inhibition zones with Candida albicans, while the negative control produce no observable zones. The inhibitory zone was measured with respect to the extract concentration in 24 and $48 \mathrm{~h}$. This assay showed that the inhibitory zone was reduced while decreasing the concentration (Fig. 1).

There was significant difference between the extract and Nystatin in their inhibition activity in comparison with Candida albicanse $(\mathrm{p}<0.01)$. Minimum Inhibitory Concentration (MIC) of the ginger extract was obtained for the concentration at $2 \mathrm{mg} \mathrm{mL}^{-1}$ (1:5 dilution).

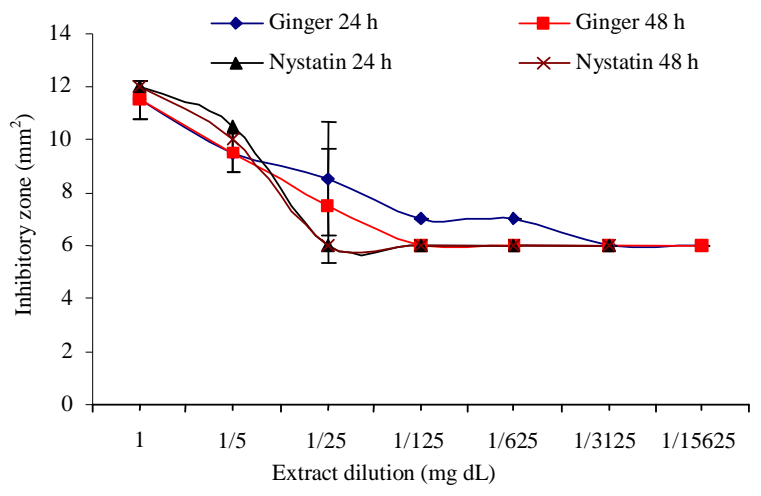

Fig. 1: Inhibitory zone in comparison with dilution

\section{DISCUSSION}

Members of the Zingiberaceae family are important in traditional medicine for the treatment of many diseases such as inflammation, morning sickness in pregnancy and many infective diseases. Significant antifungal activities were evident with extracts from members of the Zingiberacea $e^{[16-18]}$. This study showed that the extract of rhizomes of Z.officinale has pronounced inhibitory activities against Candida albicans. This result is comparable with other studies $^{[5,9,10,12]}$ suggesting that different antifungal agents are present in the Ginger extract. In the ginger rhizome there are several components which have antibacterial and anti fungal effects. The gingerol and shagelol identified as more active agents ${ }^{[13]}$.

Ginger extract containing Gingerol inhibits the growth of many bacteria and fungi in vitro and the activity might be contributed to the preventive effects of its different agents ${ }^{[13,18-21]}$.

Recent studies have focused on the effect of Ginger on the oral bacteria and fungi. Park et al. showed that crude extract of the ginger can inhibit the growth of oral bacteria in vitro ${ }^{[23]}$ which is in good agreement with our results.

\section{CONCLUSION}

Antifungal activity of the ginger extract has been reported before ${ }^{[1-13]}$. Our study focused on the effect of ginger extract on the oral species of Candida (Albicans) and showed the significant anticandidal effect the extract. Although species belonging to the Zingiberaceae family are generally regarded safe for human consumption ${ }^{[22]}$, further bio-assay guided analysis and clinical trial studies are required to approve it as an anti fungal agent for oral species. Our results suggest the ginger components as promising candidates for development of antifungal agents for topical applications.

\section{ACKNOWLEDGMENT}

The researchers would like to thank the Kerman University of Medical Sciences (vice chancellor for research) for sponsorship of the field research (Grant number: 83/53).

\section{REFERENCES}

1. Giuliana, G., G. Pizzo, M.E. Milici and R. Giangreco, 1999. In vitro activities of antimicrobial agent against candida species. J. Surg. Oral Med. Oral Pathol. Oral Radiol. Oral Endod., 87: 44-49. http://www.ncbi.nlm.nih.gov/pubmed/9927079 
2. Miller, T.F., J.I. Kelley, M.A. Jabra, L.G. Depaola, A.A. Baqui and W.A. Falker, 2001. In vitro studies of the efficacy of antimicrobials against Fungi, 2001. J. Oral Surg. Oral Pathol. Oral Radiol. Oral Endod., $\quad 91$ : 663-670. 10.1076/moe.2001.113550

3. Vianna, M.E., B.P.F. Gomes, V.B. Berder, A.A. Zaia, C.R. Feraz and F.J. Souzafilho, 2004. In vitro evaluation of the antimicrobial activity of chlorhexidine and sodium hypochlorite. J. Oral Surg. Oral Pathol. Oral Radiol. Oral Endod., 97: 79-84. DOI: 10.1016/s1079-2104(03)00360-3

4. Barasch, A., M.M., Safford, M.I. Depakute and D.H. Fine, 2004. Efficacy of chlorhexidine gluconate rinse for Treatment and prevention of oral candidiasis in HIV-infected children: A pilot study. J. Oral Surg Oral Pathol Oral Radiol Oral Endod., 97: 204-207. DOI: 10.1016/J.tripleo.2003.09.005

5. DeBoer, H.J., A. Kool, A. Broberg, W.R. Mziray, I. Hedberg and J.J. Levenfors, 2005. Antifungal activity of some herbal remedies from Tanzanias. J. Ethnopharmacol., $\quad 96: \quad 461-469 . \quad$ DOI: 10.1016/J.jep.2004.09.035

6. Alzoreky, N.S. and K. Nakahara, 2003. Antibacterial activity of extracts from some edible plants commonly consumed in Asia International. J. Food Microbiol., 80: 223-230. DOI: 10.1016/so168-1605(02)00169-1

7. Konning, G.H., C. Agyare and B. Ennison, 2004. Antimicrobial activity of some medicinal plants from Ghana. J. Phytother., 75: 65-67. DOI: 10.1016/J.fitote.2003.07.001

8. Adel, M. and A. Mahasneh, 1999. Antimicrobial activity of extracts of herbal used in the traditional medicine of Jordan. J. Ethnopharmacol., 64: 271-276. DOI: 10.1016/so378-8741(98)00132-9

9. Mascolo, N., R. Jain and S.C. Jain, 1998. Ethnopharmacologic investigation of ginger (Zingiber officinale). J. Ethnopharmacol., 27: 129-140. DOI: 10.1016/0378-8741(89)90085-8

10. Akoachere, J.F., R.N. Ndip, E.B. Chenwi, L.M. Ndip, T.E. Njock and D.N. Anong, 2002. Antibacterial effect of Zingiber officinale and Garcinia kola on respiratory tract pathogens. East African Med. J., 79: 588-592. DOI: 10.1002/ptr.1830

11. Habsah, M., M. Amran, M.M. Mackeen, N.H. Lajis, H. Kikuzaki, N.I. Nakatan, A.A. Rahman and A.M. Hafar, 2000. Screening of Zingiberaceae extracts for antimicrobial and antioxidant activities. J. Ethnopharmacol., 72: 403-410. DOI: 10.1016/so378-8741(00)00223-3

12. Gugnani, H.C. and E.C. Ezenwanze, 1985. Antibacterial activity of extracts of ginger and African oil bean seed. J. Commun. Dis., 17: 233-236.
13. Ficker, C., M.L. Smith and K. Akpagana, 2003. Bioassay-guided isolation and identification of antifungal compounds from ginger. J. Phytother. Res., 17: 897-903. DOI: 10.1002/ptr.1335

14. Forbes, B.A., D.F. Sahm and A.S. Wessfeld, 1998. Bailey and Scott's Diagnosic Microbiology. 10th Edn., Mosby Publishers, pp: 100-102.

15. Bakri, I. and M. Doyglas, 2005. Inhibitory effect of garlic extract on oral bacteria, Arch. Oral Biol., 50: 645-651.

DOI: 10.1016/J.archoralbio.2004.12.002

16. Bliddal, H., A. Rosetzsky, P. Schlichting, M.S. Weidner, L.A. Andersen, H.H. Ibfelt, K. Christernsen and O.N. Jensen, 2000. A randomized, placebo controlled, cross-over study of ginger extracts and Ibuprofen in osteoarthritis. Osteoarthritis Cartilage, 8: 9-12. http://www.ncbi.nlm.nih.gov/pubmed/10607493

17. Mahady, G.B., S.L. Pendland, G.S. Yun, Z.Z. Lu and A. Stoia, 2003. Ginger (Zingiber officinale Roscoe) and the gingerols inhibit the growth of Cag A+ strains of Helicobacter pylori. J. Anticancer Res., 23: 3699-3702. www.iiaranticancer.org

18. Ficker, C.E., M.L. Smith, S. Susiarti, D.J. Leaman, C. Irawati and J.T. Arnason, 2003. Inhibition of Human pathogenic fungi by members of Zingiberaceae. J. Ethnopharmacol., 85: 289-293. DOI: 10.1016/s0378-8741(03)00009-6

19. Tjendraputra, E., V.H. Tran, D. Liu-Brennan, B.D. Roufogalis and C.C. Duke, 2002. Effect of ginger constituents and synthetic analogues on cyclooxygecase -2enzyme in intact cells. J. Bioorganic Chem., 29: 153-156. DOI: 10.1006/bioo.2001.1208

20. Ippoushi, K., K. Azuma, H. Ito, H. Horie and H.M. Higashio, 2003. Gingerol inhibits nitric oxide synthesis in activated J 774.1 mouse macrophages and prevents peroxynitrite-induced oxidant and nittation reactions. J. Life Sci., 73: 3427-3437. DOI: $10.1016 / J . l f s .2003 .06 .022$

21. Endo, K., E. Kanno and Y. Oshima, 1990. Structures of antifungal diarylheptenones, gingerenones $\mathrm{A}, \mathrm{B}, \mathrm{C}$ and isogingerenone $\mathrm{B}$, isolated from the rhiomes of Zingiber officinale. J. Phytochem., 29: 797-799. http:www.elsvier.nl/inca/publications/store/2/7/3/

22. Weidner, M.S. and K. Sigwart, 2000. The safety of a ginger extract in the rat, J. Ethno Pharmacol., 73: 513-520. DOI: 10.1016/s0378-8741(00)00340-8

23. Park, M., J. Bae and D.S. Lee, 2008. Antibacterial activity of (10)-Gingerol and (12)-Gingerol isolated from Ginger Rhizome against periodontal bacteria. J. Phytother. Res., 22: 1446-1449. DOI: 10.1002/ptr.2473 